\title{
The Impact of Selected Cytokines in the Follow-Up of Normal Pressure Hydrocephalus
}

\author{
L. SOSVOROVA ${ }^{1}$, M. MOHAPL ${ }^{2}$, J. VCELAK ${ }^{3}$, M. HILL ${ }^{1}$, J. VITKU $^{1}$, R. HAMPL ${ }^{1}$ \\ ${ }^{1}$ Department of Steroids and Proteofactors, Institute of Endocrinology, Prague, Czech Republic, \\ ${ }^{2}$ Department of Neurosurgery, Military University Hospital Prague, Czech Republic, ${ }^{3}$ Department \\ of Molecular Endocrinology, Institute of Endocrinology, Prague, Czech Republic
}

Received May 6, 2015

Accepted May 20, 2015

\begin{abstract}
Summary
Cytokines are widely known mediators of inflammation accompanying many neurodegenerative disorders including normal pressure hydrocephalus (NPH). NPH is caused by impaired cerebrospinal fluid (CSF) reabsorption and treated by surgical shunt insertion. The diagnostics is still complicated and the shunt effect is not durable; after several years, dementia may develop. In the clinical practice, biomarkers support the diagnostics as well as the further time course of many neurodegenerative diseases. Until recently, no reliable biomarker for NPH was evaluated. The attempt of this review was to make a survey concerning cytokines as possible NPH markers. Among all reviewed cytokines, the most promising are CSF IL-10 and IL-33, enabling to follow-up the disease progression and monitoring the effectiveness of the shunt insertion.
\end{abstract}

\section{Key words}

Normal pressure hydrocephalus $\bullet$ Cytokine $\bullet$ Cerebrospinal fluid $\bullet$ Ventriculoperitoneal shunt $\bullet$ Neurodegeneration

\section{Corresponding author}

L. Sosvorova, Department of Steroids and Proteofactors, Institute of Endocrinology, Narodni 8, 11694 Prague, Czech Republic. E-mail: Isosvorova@endo.cz

\section{Introduction}

Cytokines are small protein molecules involved in cell signaling. They play major roles in the inflammatory processes within and outside the brain and have both beneficial and detrimental effects on the central nervous system (CNS) (Rothwell 2003). Inflammatory processes, including the cytokine action, usually contribute to disease progression (Wyss-Coray and Mucke 2002, Cunningham et al. 2009). The brain tissue responds to varied pathological stimuli differently than organs in the periphery. Peripheral immune cells cannot commonly penetrate into the CNS across the blood brain barrier, while in an inflammation affected brain this barrier is breached, enabling immunocompetent cells to infiltrate into the afflicted area (Lossinsky and Shivers 2004, Hampl et al. 2015). CNS is the most sensitive organ of the body with limited regenerative potential and rapid dissemination of inflammation (Lossinsky and Shivers 2004). Systemic and brain inflammation were reported for many neurodegenerative diseases (Alzheimer disease, Parkinson disease, multiple sclerosis), including normal pressure hydrocephalus (NPH) (Blum-Degena et al. 1995, Mogi et al. 1996, Tarkowski et al. 2003, Li et al. 2007, Seppi et al. 2014).

\section{Normal pressure hydrocephalus}

$\mathrm{NPH}$ is one of the treatable neurodegenerative diseases, affecting predominately elderly people. It is caused by altered cerebrospinal fluid (CSF) reabsorption and metabolism affecting brain homeostasis. Increased CSF volume can result in the damage of brain tissue and several brain disturbances. NPH is manifested clinically as balance impairment, urinary incontinence and dementia development (Adams et al. 1965, Rigamonti 2014). It is important to mention that NPH is the reason of about $5 \%$ of all dementia cases (Relkin et al. 2005). The degenerative changes accompanying NPH may be reversible when they are early recognized and treated properly. The early diagnosis of NPH is difficult because 
of various disease manifestations and overlap with other neurological disorders, which may also present the above-mentioned symptoms common in elderly. It could be easily mistaken for other neurodegenerative disorders, which makes NPH one of the important misdiagnosed diseases worldwide (Brean et al. 2009, Jaraj et al. 2014).

The most frequent therapeutic approach to NPH is the ventriculoperitoneal shunt insertion, connecting the brain ventricles to abdominal cavity, where the excessive CSF volume can be absorbed (Iseki et al. 2009, Reddy et al. 2014). CSF shunting can lead to partial or complete amelioration of the patient's state with full or partial return to premorbid social and health condition (Rigamonti 2014). Unfortunately the effect of the shunt is not durable. Recent data showed that nearly half of the initially well treated NPH patients eventually developed NPH-related dementia within a 4.7 years median followup. NPH-related degenerative changes of the brain appear usually early in the course of the disease, stressing the role of timely diagnostics (Koivisto et al. 2013). Diagnosis at the early stage gives patients high probability of all symptoms disappearing after shunt insertion (Kazui et al. 2013, Yamamoto et al. 2013).

\section{NPH biomarkers}

Biomarkers have been traditionally used in clinical practice to support the diagnosis, or monitor its progression by examining their levels longitudinally. Though the number of studies following the patient's outcome after the shunt insertion is increasing, no biomarker has fulfilled so far criteria required for differential diagnosis of various neurodegenerative disorders with respect on NPH (Rigamonti 2014).

$\mathrm{CSF}$ is the major constituent of the extracellular space in the brain. It participates in the free exchange of the most of biochemical products and therefore can better reflect the physiological or pathophysiological processes occurring in the CNS than the plasma levels (Tarnaris et al. 2006). For that reason, the CSF is the first biological material at stake in the search for suitable biomarkers in neurodegenerative diseases including NPH. A great advantage is the possibility to collect the CSF longitudinally after the shunt insertion.

The current search for such biomarkers is mainly focused on the proteins in the CSF ( $\tau$-protein, amyloid- $\beta$, soluble amyloid precursor protein - aAPPa, light chain neurofilament protein), especially for the differentiation of NPH and Alzheimer disease. No biomarker, however, has also brought any progress in distinguishing between NPH and Parkinson disease (Rigamonti 2014). According to their physiological and pathophysiological properties and function, cytokines may be a future promising analytes in the biomarker research.

\section{Cytokines in NPH}

In subjects suffering from NPH, several studies reporting various cytokine levels were published, predominantly in CSF. The only one study (Rota et al. 2006) followed up the serum levels of several cytokines in NPH subjects, but no differences in comparison with Alzheimer disease patients were found. A brief review summarizing the current knowledge concerning CSF cytokines in NPH subjects is shown in Table 1.

\section{Pro-inflammatory cytokines - IL-1 and IL-6 family}

Among all cytokines, the most discussed one in the relation to neurodegenerative disorders is IL-1. The IL-1 family is composed of its agonists, a series of protein factors, from which IL- $1 \beta$ plays the major role in brain neurodegeneration (Simi et al. 2007). This cytokine is not generally expressed or secreted under physiological conditions; its major activity seems to be limited to diseases (Dinarello and Thompson 1991). IL-1 $\beta$ initiates or augments multiple responses increasing the defence processes against tissue injury within as well as outside CNS. It leads to the development of inflammation following by the activation of immune cells and the formation of IL-6 (Kishimoto et al. 1992, Rothwell and Luheshi 2000, Janeway et al. 2004, Chakraborty et al. 2010). Thus, together with elevated CSF IL-1 $\beta$ in neurodegenerative diseases including NPH, elevated levels of pro-inflammatory IL-6 were also reported (Blum-Degena et al. 1995, Mogi et al. 1996, Sosvorova et al. 2014). Pro-inflammatory IL-6 have direct effects on both peripheral tissues and CNS, by affecting neurons and lymphocytes and inducing acute phase protein synthesis (Kishimoto et al. 1992, Janeway et al. 2004). Together with elevated IL-1 $\beta$, the elevated CSF IL-6 levels were reported in neurodegenerative diseases such as Alzheimer and Parkinson disease (Blum-Degena et al. 1995, Mogi et al. 1996), as well as in subjects suffering from subarachnoid hemorrhage, schizophrenia and depressive disorders (Mathiesen et al. 1993, Sasayama et al. 2013). Both cytokines also participate in the NPH 
development (Sosvorova et al. 2014).

One of the recently discovered IL-1 family members is IL-33. It is expressed after pro-inflammatory stimulation by many cell types, especially in the brain and spinal cord and it is also thought to be released on cell lysis (Schmitz et al. 2005, Liew et al. 2010). IL-33 can induce the proliferation of brain microglia and also enhance IL-1 $\beta$ expression. At the same time it also induces the expression of anti-inflammatory IL-10 (see below).

Table 1. Altered cerebrospinal fluid cytokines in various types of adult hydrocephalus.

\begin{tabular}{|c|c|c|c|}
\hline Cytokine & Studied group & Main findings & Reference \\
\hline IL- $1 \beta$ & NPH, Alzheimer disease & Lower in NPH compared to Alzheimer disease & (Cacabelos et al. 1991) \\
\hline IL-6 & $\begin{array}{l}\text { Various types of adult } \\
\text { hydrocephalus }\end{array}$ & $\begin{array}{l}\text { Increased in hydrocephalus following hemorrhage } \\
\text { and embolization of unrupted intracranial } \\
\text { aneurysms compared to normal controls }\end{array}$ & (Killer et al. 2010) \\
\hline IL-8 & $\begin{array}{l}\text { Various types of adult } \\
\text { hydrocephalus }\end{array}$ & $\begin{array}{l}\text { Increased in hydrocephalus following hemorrhage } \\
\text { compared to normal controls }\end{array}$ & (Killer et al. 2010) \\
\hline \multirow{5}{*}{ TGF- $\beta$} & $\mathrm{NPH}$ & $\begin{array}{l}\text { Increased after ventriculostomy compared to the } \\
\text { samples collected before the procedure }\end{array}$ & (Pyykko et al. 2014) \\
\hline & $\mathrm{NPH}$ & $\begin{array}{l}\text { Elevated in NPH compared to controls without } \\
\text { neurological diseases }\end{array}$ & (Li et al. 2007) \\
\hline & NPH, Alzheimer disease & Lower in NPH compared to Alzheimer disease & (Rota et al. 2006) \\
\hline & Communicating & & \\
\hline & $\begin{array}{l}\text { hydrocephalus after } \\
\text { subarachnoid hemorrhage } \\
\text { (SAH) }\end{array}$ & $\begin{array}{l}\text { Higher in communicating hydrocephalus after } \\
\text { SAH compared to controls without hydrocephalus }\end{array}$ & $\begin{array}{l}\text { (Kitazawa and Tada } \\
\text { 1994) }\end{array}$ \\
\hline \multirow[t]{2}{*}{$\mathrm{TNF} \alpha$} & $\mathrm{NPH}$ & $\begin{array}{l}\text { Lower in NPH compared to controls without } \\
\text { hydrocephalus }\end{array}$ & (Leinonen et al. 2011) \\
\hline & $\mathrm{NPH}$ & $\begin{array}{l}\text { Increased in NPH, reversed following shunt } \\
\text { implantation in parallel with the clinical } \\
\text { improvement, compared to the controls }\end{array}$ & (Tarkowski et al. 2003) \\
\hline
\end{tabular}

\section{Pro-inflammatory cytokines - IL-17 family}

The IL-17 family is a heterogeneous group, including both pro-inflammatory (IL-17A and IL-17F) and anti-inflammatory cytokines (IL-17E is also known as IL-25). Among all, the biological functions of IL-17A and IL-17F are best understood. These two cytokines are known to mediate proinflammatory responses, with certain differences depending on the type and site of inflammation (Ishigame et al. 2009, Jin and Dong 2013). They are produced by specialized T cells, called Th17 cells involved in the adaptive immunity. IL-17A, as other pro-inflammatory cytokines, induces the production of IL-1 $\beta$, IL-6 and TNF- $\alpha$ (Jovanovic et al. 1998, Witowski et al. 2004). Uncontrolled production of IL-17A can result in excessive pro-inflammatory cytokine expression and chronic inflammation leading to tissue damage and autoimmunity. All IL-17 family cytokines are associated with several autoimmune diseases, including multiple sclerosis and rheumatoid arthritis (Ishizu et al. 2005, Jin and Dong 2013). Cytokines produced by Th17 cells are the main power that manage the CNS inflammation and formation of lesions (Park et al. 2005). The overproduction of IL-17A may deteriorate the inflammatory reactions and contribute to tissue injury.

\section{Anti-inflammatory cytokines}

Anti-inflammatory interleukines play opposite functions to the pro-inflammatory ones. Among them the effect of IL-4 and IL-10 is the best understood. Generally, they can suppress pro-inflammatory cytokine production and action, subsequently protecting the brain from excessive immune reaction (Hart et al. 1989, Park et al. 
2007, Rubio-Perez and Morillas-Ruiz 2012). IL-4 is thus a significant player in the regulation of brain immunity, with consequences for neurological and neurodegenerative disorders (Gadani et al. 2012, Sosvorova et al. 2014).

Another anti-inflammatory cytokine, IL-10, is also involved in the pathophysiology of CNS disorders. It inhibits the production of reactive oxygen intermediates (Krakauer 1995) and is considered to be an efficient modulator of glial activation, maintaining a balance between pro- and anti-inflammatory cytokines in the CNS (Sawada et al. 1999, Qian et al. 2006, Park et al. 2007). A neuroprotective effect of IL-10 was reported in Parkinson disease (Qian et al. 2006), lower levels of CSF IL-10 were found in patients with Alzheimer disease (Remarque et al. 2001), contrasting with previously published elevated levels in NPH (Sosvorova et al. 2014). Our observation shows IL-10 as an analyte having potential in the differential diagnosis of the latter two diseases.

\section{The follow-up of cytokines in CSF and plasma after shunt insertion}

As described above, the only differences in cytokine composition between NPH subjects and controls were found in CSF. In our previous study (Sosvorova et al. 2014), the levels of IL-1 $\beta$, IL-4, IL-6, IL-10, IL-17A, IL-17F, IL-21, IL-22, IL-23, IL-25, IL-31, IL-33, INF- $\gamma$, soluble CD40 ligand (sCD40L) and TNF- $\alpha$ in CSF from patients diagnosed with NPH were investigated and compared to the controls. Increased CSF levels of IL-1 $\beta$ and IL-6 in NPH were found, reflecting the inflammatory changes in the brain. Their levels decreased during the lumbar drainage. It can be explained by activation of defense mechanisms suppressing the detrimental process in the brain. No changes were observed in plasma.

The same patient group (Sosvorova et al. 2014) was further followed-up for 2 years from the shunt insertion, in order to evaluate possible prognostic laboratory markers of the patients' outcome. As shown in Figure 1, the CSF pro-inflammatory cytokines IL-1 $\beta$ and IL-6 decreased after shunt insertion, reflecting the inflammatory changes in the NPH brain and the amelioration of the patient's state after shunt insertion. The constant CSF IL-1 $\beta$ and IL-6 levels within 2 years after shunt insertion confirm the durable positive effect of shunt insertion. The time course of CSF antiinflammatory IL-4 coincides with the elevation of the abovementioned cytokines.
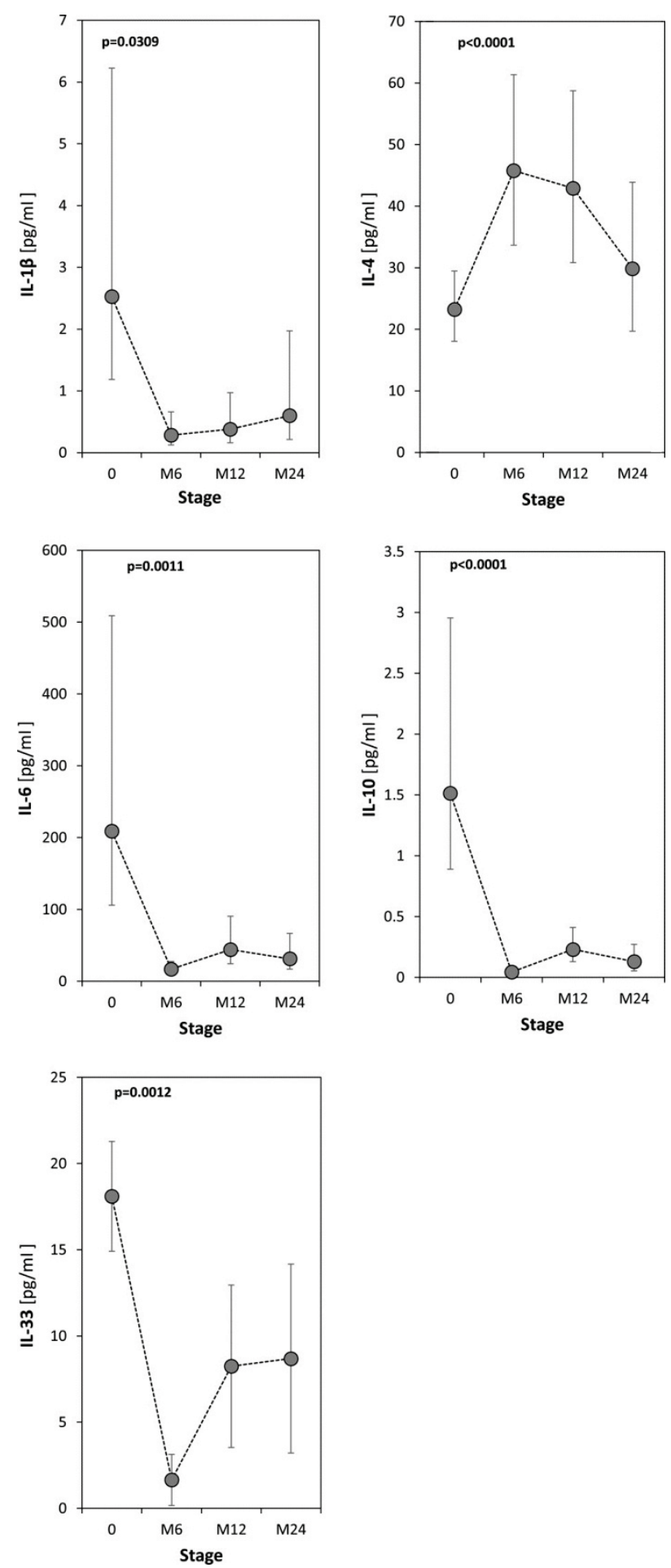

Fig. 1. The significantly changed cerebrospinal fluid (CSF) cytokine levels in subjects with diagnosed normal pressure hydrocephalus, who underwent ventriculoperitoneal shunt implantation. The stage indicates the period when CSF was collected: 0 means the period when the disease was diagnosed; M6 means the period within 6 months from the shunt insertion; M12 means the period within 12 months from the shunt insertion; M24 means the period within 24 months from the shunt insertion. The statistical significances between stages are indicated above each graph. The stages differ significantly, when the confidence intervals do not overlap. The statistics was performed using repeated measures of the ANOVA model followed by least significant difference (LSD) multiple comparisons. 
The elevated CSF IL-10 levels in NPH were found in our previous study (Sosvorova et al. 2014), the two-years follow-up showed that the CSF IL-10 as well as IL-33 significantly decreased after 6 months from shunt insertion. After 12 months their levels increased again, but did not reach the levels before shunt insertion and remained stable within 24 months. Considering the time-related CSF IL-33 changes, this pro-inflammatory cytokine appear as possible marker for the follow of the development and progression of NPH. The prompt decrease of its levels in CSF reflected the rapid patient's amelioration after shunt insertion. Concerning CSF IL-10, its decrease after shunt insertion and its stabilization at levels lower than $0.5 \mathrm{pg} / \mathrm{ml}$ for 2 years makes CSF IL-10 possible diagnostic tool in the followup to the patient's outcome after shunt insertion.

It is also worth mentioning that no significant changes of IL-17A and IL-17F CSF levels were observed during the 2-years monitoring period. It shows, that they are not suitable indicators of the disease progress. The same situation concerns pro-inflammatory IL-21, IL-22, IL-23, IL-31, TNF- $\alpha$ and INF- $\gamma$.

\section{Conclusion}

In this review we summarized the current knowledge concerning the role of pro- and antiinflammatory cytokines in the NPH with respect to the assessment of their possible role in the early diagnostics as well as for the follow-up of the disease's progress. This review is supplemented by our exposure on the follow-up of selected cytokine changes. The most promising cytokines are CSF IL-10 and IL-33, applicable in NPH diagnosis as well as in the observation of effectiveness of the shunt insertion. In the subsequent study, we will evaluate the clinical significance of above mentioned cytokines.

\section{Conflict of Interest}

There is no conflict of interest.

\section{Acknowledgements}

This work was supported by grant No. NT/12349 of the Internal Grant Agency of the Czech Ministry of Health and by the project MZ CR for conceptual development of research organization 00023761 (Institute of Endocrinology, Prague, Czech Republic).

\section{References}

ADAMS R, FISHER C, HAKIM S, OJEMANN R, SWEET W: Symptomatic occult hydrocephalus with normal cerebrospinal-fluid pressure: a treatable syndrome. New Engl J Med 273: 117-126, 1965.

BLUM-DEGENA D, MÜLLER T, KUHN W, GERLACH M, PRZUNTEK H, RIEDERER P: Interleukin-1 $\beta$ and interleukin-6 are elevated in the cerebrospinal fluid of Alzheimer's and de novo Parkinson's disease patients. Neurosci Lett 202: 17-20, 1995.

BREAN A, FREDO HL, SOLLID S, MULLER T, SUNDSTROM T, EIDE PK: Five-year incidence of surgery for idiopathic normal pressure hydrocephalus in Norway. Acta Neurol Scand 120: 314-316, 2009.

CACABELOS R, BARQUERO M, GARCIA P, ALVAREZ X, VARELA DSE: Cerebrospinal fluid interleukin-1 beta (IL-1 beta) in Alzheimer's disease and neurological disorders. Method Find Exp Clin 13: 455-458, 1991.

CHAKRABORTY S, KAUSHIK DK, GUPTA M, BASU A: Inflammasome signaling at the heart of central nervous system pathology. $J$ Neurosci Res 88: 1615-1631, 2010.

CUNNINGHAM C, CAMPION S, LUNNON K, MURRAY CL, WOODS JF, DEACON RM, RAWLINS JNP, PERRY VH: Systemic inflammation induces acute behavioral and cognitive changes and accelerates neurodegenerative disease. Biol Psychiat 65: 304-312, 2009.

DINARELLO CA, THOMPSON RC: Blocking IL-1: interleukin 1 receptor antagonist in vivo and in vitro. Immunol Today 12: 404-410, 1991.

GADANI SP, CRONK JC, NORRIS GT, KIPNIS J: IL-4 in the brain: a cytokine to remember. $J$ Immunol 189: 42134219, 2012.

HAMPL R, BICIKOVA M, SOSVOROVA L: Hormones and the blood-brain barrier. Horm Mol Biol Clin Investig 21: 159-164, 2015.

HART PH, VITTI GF, BURGESS DR, WHITTY GA, PICCOLI DS, HAMILTON JA: Potential antiinflammatory effects of interleukin 4: suppression of human monocyte tumor necrosis factor alpha, interleukin 1, and prostaglandin E2. Proc Natl Acad Sci USA 86: 3803-3807, 1989. 
ISEKI C, KAWANAMI T, NAGASAWA H, WADA M, KOYAMA S, KIKUCHI K, ARAWAKA S, KURITA K, DAIMON M, MORI E, KATO T: Asymptomatic ventriculomegaly with features of idiopathic normal pressure hydrocephalus on MRI (AVIM) in the elderly: a prospective study in a Japanese population. J Neurol Sci 277: 54-57, 2009.

ISHIGAME H, KAKUTA S, NAGAI T, KADOKI M, NAMBU A, KOMIYAMA Y, FUJIKADO N, TANAHASHI Y, AKITSU A, KOTAKI H, SUDO K, NAKAE S, SASAKAWA C, IWAKURA Y: Differential roles of interleukin-17A and $-17 \mathrm{~F}$ in host defense against mucoepithelial bacterial infection and allergic responses. Immunity 30: 108-119, 2009.

ISHIZU T, OSOEGAWA M, MEI FJ, KIKUCHI H, TANAKA M, TAKAKURA Y, MINOHARA M, MURAI H, MIHARA F, TANIWAKI T, KIRA J: Intrathecal activation of the IL-17/IL-8 axis in opticospinal multiple sclerosis. Brain 128: 988-1002, 2005.

JANEWAY C, TRAVERS P, WALPORT M, SHLOMCHIK M: An introduction to immunobiology and innate imunity. In: Immunobiology. $6^{\text {th }}$ edition. LAWRENCE E (ed.), Garland Science, New York, 2004, pp 1-100.

JARAJ D, RABIEI K, MARLOW T, JENSEN C, SKOOG I, WIKKELSO C: Prevalence of idiopathic normal-pressure hydrocephalus. Neurology 82: 1449-1454, 2014.

JIN W, DONG C: IL-17 cytokines in immunity and inflammation. Emerg Microbes Infect 2: e60, 2013.

JOVANOVIC DV, Di BATTISTA JA, MARTEL-PELLETIER J, JOLICOEUR FC, HE Y, ZHANG M, MINEAU F, PELLETIER J-P: IL-17 stimulates the production and expression of proinflammatory cytokines, IL- $\beta$ and TNF- $\alpha$, by human macrophages. J Immunol 160: 3513-3521, 1998.

KAZUI H, MORI E, OHKAWA S, OKADA T, KONDO T, SAKAKIBARA R, UEKI O, NISHIO Y, ISHII K, KAWAGUCHI T, ISHIKAWA M, TAKEDA M: Predictors of the disappearance of triad symptoms in patients with idiopathic normal pressure hydrocephalus after shunt surgery. J Neurol Sci 328: 64-69, 2013.

KILLER M, ARTHUR A, AL-SCHAMERI AR, BARR J, ELBERT D, LADURNER G, SHUM J, CRUISE G: Cytokine and growth factor concentration in cerebrospinal fluid from patients with hydrocephalus following endovascular embolization of unruptured aneurysms in comparison with other types of hydrocephalus. Neurochem Res 35: 1652-1658, 2010.

KISHIMOTO T, AKIRA S, TAGA T: Interleukin-6 and its receptor: a paradigm for cytokines. Science 258: 593-597, 1992.

KITAZAWA K, TADA T: Elevation of transforming growth factor-beta 1 level in cerebrospinal fluid of patients with communicating hydrocephalus after subarachnoid hemorrhage. Stroke 25: 1400-1404, 1994.

KOIVISTO AM, ALAFUZOFF I, SAVOLAINEN S, SUTELA A, RUMMUKAINEN J, KURKI M, JÄÄSKELÄINEN JE, SOININEN H, RINNE J, LEINONEN V: Poor cognitive outcome in shunt-responsive idiopathic normal pressure hydrocephalus. Neurosurgery 72: 1-8, 2013.

KRAKAUER T: IL-10 inhibits the adhesion of leukocytic cells to IL-1-activated human endothelial cells. Immunol Lett 45: $61-65,1995$.

LEINONEN V, MENON LG, CARROLL RS, DELLO IACONO D, GREVET J, JAASKELAINEN JE, BLACK PM: Cerebrospinal fluid biomarkers in idiopathic normal pressure hydrocephalus. Int J Alzheimers Dis 2011: 1-6, 2011.

LI X, MIYAJIMA M, JIANG C, ARAI H: Expression of TGF-betas and TGF-beta type II receptor in cerebrospinal fluid of patients with idiopathic normal pressure hydrocephalus. Neurosci Lett 413: 141-144, 2007.

LIEW FY, PITMAN NI, MCINNES IB: Disease-associated functions of IL-33: the new kid in the IL-1 family. Nat Rev Immunol 10: 103-110, 2010.

LOSSINSKY A, SHIVERS R: Structural pathways for macromolecular and cellular transport across the blood-brain barrier during inflammatory conditions. Review. Histol Histopathol 19: 535-564, 2004.

MATHIESEN T, ANDERSSON B, LOFTENIUS A, VON HOLST H: Increased interleukin-6 levels in cerebrospinal fluid following subarachnoid hemorrhage. J Neurosurg 78: 562-567, 1993.

MOGI M, HARADA M, NARABAYASHI H, INAGAKI H, MINAMI M, NAGATSU T: Interleukin (IL)-1 $\beta$, IL-2, IL-4, IL-6 and transforming growth factor- $\alpha$ levels are elevated in ventricular cerebrospinal fluid in juvenile parkinsonism and Parkinson's disease. Neurosci Lett 211: 13-16, 1996. 
PARK H, LI Z, YANG XO, CHANG SH, NURIEVA R, WANG Y-H, WANG Y, HOOD L, ZHU Z, TIAN Q: A distinct lineage of CD4 $\mathrm{T}$ cells regulates tissue inflammation by producing interleukin 17. Nat Immunol $\mathbf{6}$ : 1133-1141, 2005.

PARK KW, LEE HG, JIN BK, LEE YB: Interleukin-10 endogenously expressed in microglia prevents lipopolysaccharide-induced neurodegeneration in the rat cerebral cortex in vivo. Exp Mol Med 39: 812-819, 2007.

PYYKKO OT, LUMELA M, RUMMUKAINEN J, NERG O, SEPPALA TT, HERUKKA SK, KOIVISTO AM, ALAFUZOFF I, PULI L, SAVOLAINEN S, SOININEN H, JAASKELAINEN JE, HILTUNEN M, ZETTERBERG H, LEINONEN V: Cerebrospinal fluid biomarker and brain biopsy findings in idiopathic normal pressure hydrocephalus. PloS One 9: e91974, 2014.

QIAN L, HONG J-S, FLOOD P: Role of microglia in inflammation-mediated degeneration of dopaminergic neurons: neuroprotective effect of interleukin 10. J Neural Transm 70 (Suppl): 367-371, 2006.

REDDY GK, BOLLAM P, CALDITO G: Long-term outcomes of ventriculoperitoneal shunt surgery in patients with hydrocephalus. World Neurosurg 81: 404-410, 2014.

RELKIN N, MARMAROU A, KLINGE P, BERGSNEIDER M, BLACK PM: Diagnosing idiopathic normal-pressure hydrocephalus. Neurosurgery 57: 4-16, 2005.

REMARQUE EJ, BOLLEN EL, WEVERLING-RIJNSBURGER AWE, LATERVEER JC, BLAUW GJ, WESTENDORP RGJ: Patients with Alzheimer's disease display a pro-inflammatory phenotype. Exp Gerontol 36: 171-176, 2001.

RIGAMONTI D: Adult Hydrocephalus. Cambridge University Press, New York, 2014.

ROTA E, BELLONE G, ROCCA P, BERGAMASCO B, EMANUELLI G, FERRERO P: Increased intrathecal TGF-beta1, but not IL-12, IFN-gamma and IL-10 levels in Alzheimer's disease patients. Neurol Sci 27: 33-39, 2006.

ROTHWELL N: Interleukin-1 and neuronal injury: mechanisms, modification, and therapeutic potential. Brain Behav Immun 17: 152-157, 2003.

ROTHWELL NJ, LUHESHI GN: Interleukin 1 in the brain: biology, pathology and therapeutic target. Trends Neurosci 23: 618-625, 2000.

RUBIO-PEREZ JM, MORILLAS-RUIZ JM: A review: inflammatory process in Alzheimer's disease, role of cytokines. TheScientificWorldJournal 2012: 756357, 2012.

SASAYAMA D, HATTORI K, WAKABAYASHI C, TERAISHI T, HORI H, OTA M, YOSHIDA S, ARIMA K, HIGUCHI T, AMANO N, KUNUGI H: Increased cerebrospinal fluid interleukin-6 levels in patients with schizophrenia and those with major depressive disorder. J Psychiatr Res 47: 401-406, 2013.

SAWADA M, SUZUMURA A, HOSOYA H, MARUNOUCHI T, NAGATSU T: Interleukin-10 inhibits both production of cytokines and expression of cytokine receptors in microglia. $J$ Neurochem 72: 1466-1471, 1999.

SCHMITZ J, OWYANG A, OLDHAM E, SONG Y, MURPHY E, MCCLANAHAN TK, ZURAWSKI G, MOSHREFI M, QIN J, LI X: IL-33, an interleukin-1-like cytokine that signals via the IL-1 receptor-related protein ST2 and induces T helper type 2-associated cytokines. Immunity 23: 479-490, 2005.

SEPPI D, PUTHENPARAMPIL M, FEDERLE L, RUGGERO S, TOFFANIN E, RINALDI F, PERINI P, GALLO P: Cerebrospinal fluid IL-1 $\beta$ correlates with cortical pathology load in multiple sclerosis at clinical onset. J Neuroimmunol 270: 56-60, 2014.

SIMI A, TSAKIRI N, WANG P, ROTHWELL NJ: Interleukin-1 and inflammatory neurodegeneration. Biochem Soc Trans 35: 1122-1126, 2007.

SOSVOROVA L, VCELAK J, MOHAPL M, VITKU J, BICIKOVA M, HAMPL R: Selected pro- and antiinflammatory cytokines in cerebrospinal fluid in normal pressure hydrocephalus. Neuro Endocrinol Lett 35: 586-593, 2014.

TARKOWSKI E, TULLBERG M, FREDMAN P, WIKKELSO C: Normal pressure hydrocephalus triggers intrathecal production of TNF-alpha. Neurobiol Aging 24: 707-714, 2003.

TARNARIS A, WATKINS LD, KITCHEN ND: Biomarkers in chronic adult hydrocephalus. Cerebrospinal Fluid Res 3: $11,2006$. 
WITOWSKI J, KSIAZEK K, JORRES A: Interleukin-17: a mediator of inflammatory responses. Cell Mol Life Sci 61: $567-579,2004$.

WYSS-CORAY T, MUCKE L: Inflammation in neurodegenerative disease - a double-edged sword. Neuron 35: 419-432, 2002.

YAMAMOTO D, KAZUI H, WADA T, NOMURA K, SUGIYAMA H, SHIMIZU Y, YOSHIYAMA K, YOSHIDA T, KISHIMA H, YAMASHITA F, YOSHIMINE T, TAKEDA M: Association between milder brain deformation before a shunt operation and improvement in cognition and gait in idiopathic normal pressure hydrocephalus. Dement Geriatr Cogn Disord 35: 197-207, 2013. 